Grant-in-Aid for Scientific Research (S)

Real Estate Markets, Financial Crisis, and Economic Growth

: An Integrated Economic Approach

Working Paper Series No.68

Inefficiency in Rice Production and Land Use:

A Panel Study of Japanese Rice Farmers

Kazuo OGAWA

August, 2017

HIT-REFINED PROJ ECT

Institute of Economic Research, Hitotsubashi University

Naka 2-1, Kunitachi-city, Tokyo 186-8603, J APAN

Tel: +81-42-580-9145

E-mail: hit-refined-sec @ier.hit-u.ac.jp

http://www.ier.hit-u.ac.jp/hit-refined/ 
August 2017

\title{
Inefficiency in Rice Production and Land Use: A Panel Study of Japanese Rice Farmers*
}

\author{
Kazuo OGAWA
}

College of Foreign Studies

Kansai Gaidai University

\begin{abstract}
In this study, an empirical analysis was conducted on the behavior of Japanese rice producers from the standpoint of efficiency in production by using the panel data from the Rice Production Cost Statistics by the Ministry of Agriculture, Forestry and Fisheries. The stochastic frontier production function, which comprises four production factors (land, labor, capital stock, and materials), was estimated and the inefficiency indices of production were calculated. Based on this information, the efficient and inefficient rice producers were identified, and the factor demand behavior and characteristics of the arable land utilization for rice production were compared. It was found that inefficient rice producers do not make any adjustments in employment in the short or long run, even if there is a change in the wages. In addition, it was observed that efficient rice producers who hold a large amount of the farms partitioned into small plots reduced the arable land utilization for rice production and increased productivity. However, it was noted that the certified farmers, who should be aiming at an expansion of the scale of operation and efficiency of agricultural operations, tend to reduce arable land utilization for rice cultivation and switch to other crops; moreover, the more efficient the certified farmers are, the larger the effects of such activities.
\end{abstract}

Keywords: stochastic frontier production function, productivity, factor demand, land use, rice production adjustment JEL classification: Q12, Q15, Q18

\footnotetext{
*This study is conducted as a part of the Project "Study on Corporate Finance and Firm Dynamics“undertaken at Research Institute of Economy, Trade and Industry (RIETI). This study utilizes the micro data of "Rice Production Cost Statistics” which is conducted by the Ministry of Agriculture, Forestry and Fisheries. This paper was presented at Hitotsubashi-RIETI International Workshop on Real Estate Market, Productivity, and Prices held at Research Institute of Economy, Trade and Industry in Tokyo, Japan on October 13-14, 2016. The author is grateful for extremely helpful comments and suggestions by Hiroshi Ohashi (Univ. of Tokyo), Iichiro Uesugi (Hitotsubashi Univ.) and the participants at the workshop and Discussion Paper seminar at RIETI. This research was financially supported by KAKENHI Grant-in-Aid for Scientific Research (S) \#15H05728, (B) \#16H03604 and the program of the Joint Usage/Research Center for “Behavioral Economics” at ISER, Osaka University.
} 


\section{Introduction}

Japan's demand for rice is decreasing as a secular trend. The annual per capita consumption of rice peaked in 1962, and has exhibited a consistent tendency to decline since that time. Japanese consumed $118 \mathrm{~kg}$ per capita on an average in 1962, but this figure had decreased to only $55 \mathrm{~kg}$ per capita as of 2014. In addition, domestic demand exhibited a tendency to decrease. Figure 1 shows the yield of and demand for rice as a staple food from 2004 to 2014. Almost every year, yield exceeded demand, and excess supply has continued.

Given chronic oversupply of rice, the Japanese government has been promoting a shift of crops from production of the staple food, rice, to soybeans and grains, and in addition, a change of crops to the so-called "new demand rice," which is mainly rice used as animal feed. The "Basic Plan on Food, Agriculture and Rural Areas" issued in 2015 also called for the provision of the support required for achieving an expansion of the production of rice for animal feed and other such uses. ${ }^{2}$

However, even with the shift from rice as a staple food to other crops, if the farmers in charge of producing rice as a staple food are inefficient producers, then a large tax burden will be incurred to maintain the price of rice. In fact, it is evident that, from an international perspective, the operation scale of rice cultivation in Japan is small, and its productivity is low. Figure 2 compares the harvests for rice paddy per 10 are in three countries, Australia, the United States, and Japan. In 1980, the harvests of the three countries were approximately $500 \mathrm{~kg}$ per 10 are and no major differences were observed between them; but in 2014, the figures were $1,092 \mathrm{~kg}$ and $849 \mathrm{~kg}$ per 10 are for Australia and the United States, respectively, whereas the harvest for Japan was 670 kg per 10 are. For rigorous evaluation about the switching policy from rice as a staple food to other crops, it is important to fully grasp the behavioral characteristics of rice producers from the viewpoint of efficiency.

The purpose of this study is to use the panel data from the Rice Production Cost Statistics by the Ministry of Agriculture, Forestry and Fisheries and undertake an empirical analysis of the efficiency in production by the rice-producing farming households. Specifically, the stochastic frontier production function, which comprises four production factors (land, labor, capital stock, and materials), is estimated, and the inefficiency indices of production are calculated. Based on the information, the efficient

\footnotetext{
${ }^{2}$ For example, there are direct subsidies paid to farmers for utilization of paddy fields for producing crops such as grains, soybeans, rice for feed, rice for rice flour, etc.
} 
and inefficient rice producers are identified, and the factor demand behavior and the characteristics of the arable land utilization for rice production are compared. ${ }^{3}$ In particular, the static factor demand behavior and the dynamic process of adjustment to the optimal factor level are compared between the efficient and inefficient rice producers.

Moreover, from the standpoint of exploitation of agricultural land, a comparative analysis of efficient and inefficient rice producers is conducted concerning the factors that determine arable land utilization for growing rice. Arable land utilization of fields, which reflects the shift to other crops by rice producers and the exploitation plans for fields, including fallow fields, has depended heavily on rice production adjustment policies. Our analysis can clarify the differences in the responses to such policies by the efficient and inefficient producers. In addition, our analysis can provide quantitatively useful information for formulating policies to achieve efficient arable land utilization.

Now we preview our main findings. First of all, the inefficiency indices of production were measured from the stochastic frontier production function (hereinafter, "sf production function"), and it was found that the estimated inefficiency was robust, irrespective of the type of production function or the probability distribution of the assumed inefficiency.

Based on the median of the measured inefficiency indices, the producers were divided into efficient and inefficient rice producer groups, and we found that the inefficient rice producers had the following characteristics:

1) The number of parcels (a 'parcel' refers to a gathering or complex consisting of several neighboring plots) is large

2) The profit and income per 10 are is low, and the loan balance and subsidies per 10 are are large

3) The land, capital, and labor productivity are low

4) Majority of the farmers own farms with micro plots, and few farmers own farms with relatively large-scale plots

5) Arable land utilization rate for rice production is low.

\footnotetext{
${ }^{3}$ The stochastic frontier production function, which models the production function by taking into consideration that producers deviate from the production frontier is an econometric model that was independently developed by Aigner, Lovell, and Schmidt (1977) and Meeusen and Van den Broeck
} (1977). 
In addition, a comparison between the behavior of inefficient and efficient rice producers with respect to the dynamic adjustment of factor demand revealed that the adjustment of labor input by inefficient rice producers is slow without responding to a change in wages.

Finally, an analysis was conducted on the size of the cultivated area of fields used for the production of rice and the determinants of the area planted with rice. It was found that the higher the proportion of farm area in small plots, the more likely that the producer would reduce arable land utilization for rice cultivation; and these effects were larger for the efficient producer. In addition, it was observed that certified farmers reduced arable land cultivation for rice production, and the extent of this reduction was larger for efficient producers. That is, the more efficient a certified farmer was, the more likely it was that he would use a field for something other than rice cultivation. If this situation continues, the productivity of rice production may decline further in the future. Therefore, it is necessary to design an agricultural system that has incentives for efficient rice producers to expand rice cultivation.

This study is organized as follows. The next section describes the data set used for the analysis. In section 3, a model for estimating the inefficiency of production is formulated, and the estimated results thereof are indicated. In section 4, the characteristics of the efficient and inefficient producers, based on the efficiency indices, are compared. In section 5, the dynamic and static factor demand function is estimated, and the differences in factor demand behavior between the efficient and the inefficient rice producer group is examined. Section 6 shows the results of an econometric analysis of the determinants of arable land utilization for rice production. Section 7 concludes this study.

\section{Data Set and their Characteristics}

The data employed in the analysis is the panel data of 2008 to 2013 from the Rice Production Cost Statistics (Kome Seisanhi Chosa Tokei)" by the Ministry of Agriculture, Forestry and Fisheries. The sample farmers are agricultural households that sold at least $600 \mathrm{~kg}$ of unpolished rice, from the total agricultural management units based on the 2010 World Agricultural and Forestry Census. The total number of observations from the panel data used is 5,543. Table 1 shows the number of observations of rice producers by prefecture. Now an explanation is in order on the procedure of data construction. 
The yield (Y) is the quantity $(\mathrm{kg})$ of rice that was produced as the main product. The labor input $(\mathrm{N})$ is the labor time spent on rice cultivation, and it includes both family labor and hired labor (the unit is hours). The land (L) is the area planted in rice (the unit is are). The capital stock $(\mathrm{K})$ is calculated by deflating the buildings and structures, land improvement equipment, automobiles, agricultural machinery, and tools in the fixed capital by the corresponding price indices (2010 prices), respectively, and by totaling them. The deflators corresponding to the respective items are buildings and materials, automobiles and related fees, and agricultural machinery and tools (comprehensive); the source is the "Agricultural Price Index" report by the Ministry of Agriculture, Forestry and Fisheries. The materials (M) were calculated by dividing the five materials (seed and seedling costs, fertilizer costs, agricultural chemical costs, light, heat and power costs, and various other materials costs) by the deflators contained in the “Agricultural Price Index" that respectively correspond to these five items, and deriving the sum total.

The prices corresponding to the output and four production factors were prepared as follows. The production price (p) was calculated by dividing the sales by the quantity of the rice produced as the main product. The wage rate (w) was calculated by dividing the labor costs for the rice cultivation (including family labor and hired labor) by the labor time for the rice cultivation. The land rent $\left(\mathrm{p}_{\mathrm{L}}\right)$ was calculated by dividing the total of the paid land rent and the land rent for the farmer's own land by the cultivated area of the fields. The rental price of the capital $\left(\mathrm{p}_{K}\right)$ was calculated by totaling the land improvement and water conservancy fees; the rent and fees; the depreciation costs out of the costs for buildings, automobiles, agricultural machinery, tools, and production management; paid interest; interest on the farmers' own capital and the self-supplied portion out of the building, automobile, agricultural machinery and tool costs; then, dividing the sum total by the capital stock. The materials cost ( $\mathrm{p}_{\mathrm{M}}$ ) was calculated by dividing the nominal amount total of the five items calculated above by the corresponding real amount.

Table 2 shows the descriptive statistics of the yield of rice, the four production factor input amounts, productivity, arable land utilization rate for rice production and farm area distribution. The means of yield, land, capital stock, and materials input were all twice the medians, and exhibited a right-skewed distribution. The means and medians of land productivity and labor productivity were roughly the same, although the mean of capital productivity greatly exceeded the median. The proportion of the arable land used for rice cultivation is calculated by dividing the area planted for rice cultivation by the cultivated area of the fields. The arable land utilization rate for rice 
cultivation is about $75 \%$, and the remaining portion is used either for switching to other crops or is left fallow. With regard to the farm area distribution, farms that are more than or equal to 10 are and less than or equal to 30 are account for $54 \%$ on average. In addition, it can be seen that the median is zero for the farms that have plots of greater than or equal to 30 are, and these farms are owned by some large-scale farming families.

\section{Identification and Estimation of Inefficiency in Production}

We estimated the sf production function, which comprises four production factors (land, labor, capital stock, and materials), and calculated inefficiency indices of production for individual rice producer. The index of inefficiency was calculated under two production functions, the Cobb-Douglas production function and translog production function and the two distribution functions, truncated normal and halfnormal for the probability density functions of inefficiency. ${ }^{4}$

The sf production function is specified as

$$
\begin{aligned}
\ln Y_{i t}= & f\left(\ln N_{i t}, \ln K_{i t}, \ln L_{i t}, \ln M_{i t}\right)-u_{i t}+v_{i t} \\
\text { where } Y_{i t}: \text { output in year } \mathrm{t} & \\
& N_{i t}: \text { labor input in year } \mathrm{t} \\
& K_{i t}: \text { capital stock in year } \mathrm{t} \\
& L_{i t}: \text { planted area for rice in year } \mathrm{t} \\
& M_{i t}: \text { material input in year } \mathrm{t} \\
& u_{i t}: \text { random variable representing inefficiency, } u_{i t} \geq 0 \\
& v_{i t}: \text { disturbance term } \\
& i \text { is an index of rice producer }
\end{aligned}
$$

When the production function is the Cobb-Douglas type, it is written as

$$
f\left(\ln N_{i t}, \ln K_{i t}, \ln L_{i t}, \ln M_{i t}\right)=\alpha_{N} \ln N_{i t}+\alpha_{K} \ln K_{i t}+\alpha_{L} \ln L_{i t}+\alpha_{M} \ln M_{i t}
$$

When the production function is the translog type, it is written as

\footnotetext{
${ }^{4}$ Pitt and Lee (1981) is an empirical study of the sf production function that assumes a half-normal distribution for the probability distribution of inefficiency. Battess and Coeli (1988) generalized the probability distribution function for inefficiency to a truncated normal distribution and estimated the sf production function.
} 


$$
\begin{aligned}
& f\left(\ln N_{i t}, \ln K_{i t}, \ln L_{i t}, \ln M_{i t}\right)=\alpha_{N} \ln N_{i t}+\alpha_{K} \ln K_{i t}+\alpha_{L} \ln L_{i t}+\alpha_{M} \ln M_{i t} \\
+ & \alpha_{N N}\left(\ln N_{i t}\right)^{2}+\alpha_{N K}\left(\ln N_{i t}\right)\left(\ln K_{i t}\right)+\alpha_{N L}\left(\ln N_{i t}\right)\left(\ln L_{i t}\right)+\alpha_{N M}\left(\ln N_{i t}\right)\left(\ln M_{i t}\right) \\
+ & \alpha_{K K}\left(\ln K_{i t}\right)^{2}+\alpha_{K L}\left(\ln K_{i t}\right)\left(\ln L_{i t}\right)+\alpha_{K M}\left(\ln K_{i t}\right)\left(\ln M_{i t}\right) \\
+ & \alpha_{L L}\left(\ln L_{i t}\right)^{2}+\alpha_{L M}\left(\ln L_{i t}\right)\left(\ln M_{i t}\right)+\alpha_{M M}\left(\ln M_{i t}\right)^{2}
\end{aligned}
$$

When $u_{i t}$ is distributed as truncated normal, the density function is written as

$$
\mathrm{h}\left(u_{i t}\right)=\frac{\exp \left\{-\frac{1}{2}\left(u_{i t}-\mu\right)^{2} / \sigma_{u}^{2}\right\}}{\sqrt{2 \pi} \sigma_{u}\left[1-\Phi\left(-\mu / \sigma_{u}\right)\right]} \quad u_{i t} \geq 0
$$

where $\Phi(\quad$ ): cumulative standard normal density function

When $u_{i t}$ is distributed as half-normal, $\mu=0$ in eq.(4). We assume that the disturbance term $\left(v_{i t}\right)$ is i.i.d. normal as $\mathrm{N}\left(0, \sigma_{v}^{2}\right)$.

In estimation, the year dummies, and regional dummies that classify Japan's 47 prefectures into 10 regions (Hokkaido, Tohoku, south Kanto, north Kanto and Koshin, Hokuriku, Tokai, Kinki, Chugoku, Shikoku, and Kyushu) were added to the explanatory variables. ${ }^{5}$ Table 3 shows the results of the sf production function that is estimated by the maximum likelihood method. First, let us examine the estimation results when halfnormal is assumed in the probability distribution of inefficiency. Significantly positive values are obtained for all of the coefficient estimates of the Cobb-Douglas production function (column 2 of Table 3). The elasticity of labor, capital stock, land, and materials is $0.0141,0.0048,0.9397$, and 0.0567 , respectively. ${ }^{6}$ The total elasticity is 1.0153 , which indicates increasing returns to scale. ${ }^{7,8}$ On the other hand, the estimation results

${ }^{5}$ When the model with dummy variables corresponding to the individual prefectures was estimated, converge was not attained. Therefore, we utilize the regional dummies instead.

${ }^{6}$ The obtained elasticity estimates are close to the values in Saito et al. (2010), which estimated the Cobb-Douglas production function with the microdata of the Agriculture and Forestry Census. The estimated elasticities of labor, capital stock, and land obtained by them are 0.0523-0.0678, 0.02140.0291, and 0.9571-1.0556, respectively. In their estimation, the amount of materials input has not been controlled as an explanatory variable.

${ }^{7}$ When the null hypothesis of constant returns to scale was tested by a Wald statistics, it was rejected at the $1 \%$ level.

${ }^{8}$ Kako (1979), Hayami and Kawagoe (1989), and Saito et al. (2010) have reported that increased returns to scale are prevalent in Japan's rice production. 
of the translog production function are not entirely satisfactory since many of the coefficient estimates are not significant due to multicollinearity (column 3 of Table 3).

We can measure the index of inefficiency with the method of Jondrow et al. (1982) for individual rice producers based on the coefficient estimates of the production function as:

$$
\begin{aligned}
& \mathrm{E}\left[u_{i t} \mid \varepsilon_{i t}\right] \\
& \quad \text { where } \varepsilon_{i t} \equiv v_{i t}-u_{i t}
\end{aligned}
$$

When the estimation is conducted by combining the two production functions and the two assumptions related to the probability distribution of inefficiency, four inefficiency indices are calculated. Table 4 shows the descriptive statistics of inefficiency indices that are calculated from the respective coefficient estimates of the Cobb-Douglas production function and translog production function. It is evident that the means, medians, and standard deviations of the two inefficiency indices are roughly the same size. In addition, the correlation coefficient of the two series is 0.9983 .

Next, we examine the estimation results when truncated normal is assumed for the probability distribution of inefficiency. All of the coefficient estimates of the CobbDouglas production function are significantly positive, and the elasticity of labor, capital stock, land, and materials is 0.0141, 0.0048, 0.9398, and 0.0568, respectively; thus, these estimates are roughly the same as those obtained when half-normal was assumed for the probability distribution of inefficiency (column 4 of Table 3). In addition, the total elasticity is 1.0155 , and it indicates increasing returns to scale. The estimate of the inefficiency parameter $\mu$ of truncated normal distribution is 0.0186 , but it is not statistically significant, and no major difference is observed between the estimation results when truncated normal is assumed for the probability distribution of inefficiency and the estimation results when half-normal is assumed. As for the estimation results of the translog production function, many of the coefficient estimates are not significant due to multicollinearity (column 5 of Table 3). With respect to the descriptive statistics for inefficiency that are calculated from the respective coefficient estimates of the Cobb-Douglas production function and translog production function, the means, medians, and standard deviations of the two inefficiency indices are roughly the same size, and the correlation coefficient of the two series is extremely high at 0.9983 (see Table 4).

In the above-mentioned model, it was assumed that the inefficiency of individual producers is time-invariant. Battess and Coeli (1992) relaxed this assumption and 
conducted estimation based on the specification of equation (6), wherein the inefficiency changes with time.

$$
\begin{gathered}
u_{i t}=\exp \left\{-\eta\left(t-T_{i}\right)\right\} u_{i} \\
\text { where } u_{i}: \text { random variable distributed as truncated normal, } u_{i} \geq 0 \\
T_{i} \text { : last year for i-th producer in the panel data set }
\end{gathered}
$$

Table 5 shows the estimation results of equation (6). The estimate of $\eta$ is positive at 0.0011 in the case of the Cobb-Douglas production function, and 0.0017 in the case of the translog production function; however, neither of these is statistically significant.

Based on the above results, we conclude that the inefficiency indices of production are time-invariant, and the probability distribution can be depicted by halfnormal. In addition, it was found that the inefficiency indices do not depend on the specification of the production function. Therefore, in the subsequent analysis, halfnormal will be assumed for the probability distribution of inefficiency, and we will assume the Cobb-Douglas production function, wherein stable parameters are obtained. ${ }^{9}$

4. Comparison of Behavioral Characteristics between Efficient and Inefficient Rice Producers

Based on the median of the inefficiency indices of the sf production function estimated in the preceding section, the rice producers are divided into an efficient producer group and an inefficient producer group, and the characteristics of their respective behaviors are examined.

Specifically we compare the behavioral characteristics of the efficient and inefficient rice farmers based on the following 16 items:

1) The number of parcels

2) The area planted with rice

3) The income per 10 are

\footnotetext{
${ }^{9}$ The analysis in the subsequent sections is almost entirely unaffected even if we use the inefficiency indices that are obtained under the assumption of the Cobb-Douglas production function and truncated normal distribution. Incidentally, the correlation coefficient of the inefficiency indices, when the probability distributions of inefficiency are half-normal and truncated normal, exhibits a high value of 0.8298 .
} 
4) The outstanding loan balance per 10 are

5) Land productivity

6) Capital productivity

7) Labor productivity

8) Proportion of arable land used for rice production

9) Net receipt of mutual aid money per 10 are

10) Proportion of farm area not disposed of or in lots of less than $10 \mathrm{a}$

11) Proportion of farm area in lots of more than or equal 10 a and less than 20 a

12) Proportion of farm area in lots of more than or equal 20 a and less than $30 \mathrm{a}$

13) Proportion of farm area in lots of more than or equal 30 a and less than 50 a

14) Proportion of farm area in lots of more than or equal 50 a

15) Proportion of certified farmers

16) Price per kg of the harvested rice

Some explanation is in order on some of the above variables. A parcel refers to a gathering or complex consisting of several neighboring plots. It has been claimed that the larger the number of parcels, the more the agricultural land is fragmented, the higher the rise in production costs, and the more the inefficiency. ${ }^{10}$ Items 10 to 14 provide useful information on the relationship between efficiency of production and the scale of farm area. Based on this distributional information, we can examine whether the farm size of micro plots is large in the case of inefficient producers, and whether the proportion of farm size with relatively large-scale plots is large in the case of efficient producers.

The "certified farmers" are the farmers that were certified as persons in charge of agriculture by local municipals under the "Act on Promotion of Improvement of Agricultural Management Foundation," which was established in $1993 .{ }^{11}$ In order to be selected as a certified farmer, a farmer passes through a process wherein he submits an agricultural management improvement plan to the local municipals, and they, in turn, certify an agricultural management unit that includes a farming family as a certified farmer for a period of 5 years. The “Agricultural Management Improvement Plan” describes the target for expansion of management scale over the coming 5 years, the

\footnotetext{
${ }^{10}$ Kawasaki (2010) has shown that a large number of parcels pose no obstacle to the efficiency in rice production by employing the panel data of Rice Production Cost Statistics.

${ }^{11}$ The following description about certified farmers is taken from Saito and Ohashi (2015).
} 
goals for attaining efficiency of agricultural management, etc., in a format that follows the basic conception of the local municipals. The advantages of becoming a certified farmer are that there are grants and increases in the subsidies related to agricultural production, mainly switching to new crops, and the possibility of receiving low interest finance from the Agriculture JA Bank and the Japan Finance Corporation, among others. However, the costs of becoming a certified farmer cannot be overlooked. In addition to various burdensome official procedures, cooperation in production adjustment for rice was a requirement at the stage of applying to become a certified farmer prior to 2009. It is particularly likely that the latter factor acted as a constraining condition on certified farmers on the utilization of the cultivated land for rice production. This will be examined in details in section 6.

Table 6 shows the statistics to test the equality of the means of the 16 items described above between the efficient and inefficient producer groups. The characteristics of the inefficient producers can be summarized from this table as follows:

1) The number of parcels is large

2) The income per 10 a is low, and the outstanding loan balance and the net amount of the subsidies received per 10 a are large

3) The land, capital, and labor productivity are low

4) The proportion of arable land used for rice production is low

5) The proportion of farm area that is undisposed or in micro plots less than 20 a is large, and the proportion of farm area in relatively large-scale plots more than or equal 30 a is small

6) The proportion of certified farmers is high

There are no statistically significant differences between inefficient and efficient producers as far as the area planted with rice is concerned. However, the farm area in micro plots of less than 20 are is large in the case of inefficient producers, while the proportion of farm area in relatively large-scale plots of more than or equal 30 are is large in the case of efficient producers. Moreover, the number of parcels is larger in the case of inefficient producers. This farm scale for rice production and degree of agricultural land fragmentation may have resulted in the differences in productivity. In Figure 3, the histograms of land productivity for efficient and inefficient producers are compared. 
Some may argue that efficient rice producers have increased production efficiency by producing rice of lower quality. However, this assertion is not supported since no statistically significant differences in the price per $\mathrm{kg}$ of the rice harvested can be found between the efficient and inefficient rice producers. No one will disagree that the characteristics mentioned in 1 to 5 describe the behavior of inefficient rice farmers quite well. However, the sixth characteristic, wherein the proportion of certified farmers is higher for inefficient producers, is the opposite of the intention of certified farmer selection. This case will be examined further in section 6, which conducts an econometric analysis of the determinants of the allocation of arable land to production of rice and other crops.

\section{Inefficiency in Production and Factor Demand}

This section analyzes the effects of inefficiency on factor demand in rice cultivation. We will examine the determinants of static and dynamic factor demand by rice producers by paying due attention to the relationship of factor demand to the efficiency in production.

\section{Estimation of the static factor demand function}

Firstly, when there is inefficiency in production, it is easy to see its effects on static factor demand, using a simple theoretical model. We assume that the production function is expressed as:

$$
\mathrm{Y}=\mathrm{F}(K, N, M, \bar{L}) e^{-u}
$$

where $\mathrm{Y}$ is the yield, $K, N, M$, and $L$ are the input amounts of capital stock, labor, materials, and land (given), respectively, and $\mathrm{u}$ is the non-negative variable indicating inefficiency. The necessary conditions of profit maximization are expressed as follows:

$$
\frac{\partial F}{\partial K} e^{-u}=\frac{p_{K}}{p}, \frac{\partial F}{\partial N} e^{-u}=\frac{w}{p}, \frac{\partial F}{\partial M} e^{-u}=\frac{p_{M}}{p}
$$

where $p_{K}, w, p_{M}$,and $p$ are the rental price of capital, wage rate, material price, and output price, respectively. From equation (8), the factor demand function is derived as a function of the real factor prices, the area planted with rice, and the inefficiency index.

$$
K^{*}=g_{K}\left(\frac{p_{K}}{p}, \frac{w}{p}, \frac{p_{M}}{p}, \bar{L}, u\right)
$$




$$
\begin{aligned}
N^{*} & =g_{N}\left(\frac{p_{K}}{p}, \frac{w}{p}, \frac{p_{M}}{p}, \bar{L}, u\right) \\
M^{*} & =g_{M}\left(\frac{p_{K}}{p}, \frac{w}{p}, \frac{p_{M}}{p}, \bar{L}, u\right)
\end{aligned}
$$

It can be shown that the larger the inefficiency, the more the decrease in factor demand when the second partial derivative with respect to different production factors is positive or $\frac{\partial^{2} Y}{\partial x_{i} \partial x_{j}}>0\left(x_{i}\right.$ : factor input, $\left.i \neq j\right) .{ }^{12}$ Therefore, it can be deduced that the more inefficient a rice producer, the greater the inefficiency in production, and the lesser the level of factor demand. To examine this proposition empirically, the logarithmic linear factor demand function, which takes inefficiency into consideration, is estimated. The estimation equation is specified as follows:

$$
\begin{aligned}
\ln K_{i t} & =\beta_{0 K}+\beta_{1 K} \ln \left(\frac{p_{K}}{p}\right)_{i t}+\beta_{2 K} \ln \left(\frac{w}{p}\right)_{i t}+\beta_{3 K} \ln \left(\frac{p_{M}}{p}\right)_{i t}+\beta_{4 K} \ln \overline{L_{l t}}-u_{K, i t}+v_{K, i t} \\
\ln N_{i t} & =\beta_{0 N}+\beta_{1 N} \ln \left(\frac{p_{K}}{p}\right)_{i t}+\beta_{2 N} \ln \left(\frac{w}{p}\right)_{i t}+\beta_{3 N} \ln \left(\frac{p_{M}}{p}\right)_{i t}+\beta_{4 N} \ln \overline{L_{l t}}-u_{N, i t}+v_{N, i t} \\
\ln M_{i t} & =\beta_{0 M}+\beta_{1 M} \ln \left(\frac{p_{K}}{p}\right)_{i t}+\beta_{2 M} \ln \left(\frac{w}{p}\right)_{i t}+\beta_{3 M} \ln \left(\frac{p_{M}}{p}\right)_{i t}+\beta_{4 M} \ln \overline{L_{l t}}-u_{M, i t} \\
& +v_{M, i t}
\end{aligned}
$$

where $u_{K, i t}, u_{N, i t}, u_{M, i t}$ : stochastic inefficiency term corresponding to capital stock, labor and material $\quad u_{K, i t}>0, u_{N, i t}>0, u_{M, i t}>0$ $v_{K, i t}, v_{N, i t}, v_{M, i t}:$ disturbance term corresponding to capital stock, labor and material

By calculating the correlation coefficient between the estimated inefficiency index of factor demand from equation (10), and the inefficiency index of production, which was obtained by estimating the sf production function, it is possible to test the validity of the above proposition.

Table 7 shows the estimation results of equation (10) under the assumption that the probability distribution of inefficiency is half-normal and that the error term is distributed as i.i.d. normal. The descriptive statistics of the inefficiency indices in the

\footnotetext{
12 This condition is satisfied in the Cobb-Douglas production function.
} 
three-factor demand functions are shown in Table 8. Positive correlation of 0.3560, 0.2396 , and 0.2305 were observed for the correlation coefficients of production inefficiency and inefficiency in capital, labor, and materials, respectively, which supports our proposition above. ${ }^{13}$ It is evident that the more a rice producer diverges from the production frontier, the more the factor demand also diverges from the optimal level.

Estimation of the dynamic factor demand function

The factor demand function estimated above is a static model, but if the factor demand is at a smaller level than the optimal, it is interesting to see the dynamic processes of adjusting factor demand for the efficient and the inefficient rice producers. Accordingly, the following dynamic factor demand function is estimated for the efficient and inefficient producer groups:

$$
\begin{aligned}
& \ln K_{i t}=\gamma_{0 K}+\gamma_{1 K} \ln \left(\frac{p_{K}}{p}\right)_{i t}+\gamma_{2 K} \ln \left(\frac{w}{p}\right)_{i t}+\gamma_{3 K} \ln \left(\frac{p_{M}}{p}\right)_{i t}+\gamma_{4 K} \ln K_{i, t-1}+v_{K, i t} \\
& \ln N_{i t}=\gamma_{0 N}+\gamma_{1 N} \ln \left(\frac{p_{K}}{p}\right)_{i t}+\gamma_{2 N} \ln \left(\frac{w}{p}\right)_{i t}+\gamma_{3 N} \ln \left(\frac{p_{M}}{p}\right)_{i t}+\gamma_{4 N} \ln N_{i, t-1}+v_{N, i t} \\
& \ln M_{i t}=\gamma_{0 M}+\gamma_{1 M} \ln \left(\frac{p_{K}}{p}\right)_{i t}+\gamma_{2 M} \ln \left(\frac{w}{p}\right)_{i t}+\gamma_{3 M} \ln \left(\frac{p_{M}}{p}\right)_{i t}+\gamma_{4 M} \ln M_{i, t-1}+v_{M, i t}
\end{aligned}
$$

The area planted with rice will be eventually adjusted to the optimal level in the longrun and thus is eliminated from the explanatory variables. Therefore, the explanatory variables are the factor input level of the previous year, the real factor prices of the current period, and the year dummies. In equation (11), the adjustment speed of factor demand is estimated as $1-\gamma_{4 j}(j=K, N, M)$. The producers are divided into efficient and inefficient producer groups based on the efficiency index in production and then the system GMM estimator is applied to equation (11) for each of the groups. Table 9 shows the estimation results.

A large difference in dynamic factor demand behavior was observed between the labor demand of the efficient and the inefficient producer group. Firstly, the

\footnotetext{
${ }^{13}$ The rank correlation coefficient exhibits an even higher value. Spearman's rank correlation coefficients between the inefficiency of production and the demand functions of capital, labor, and materials are $0.3805,0.3010$, and 0.2712 , respectively.
} 
adjustment speed of labor is faster for efficient producers than for inefficient producers. While the adjustment speed of the former is 0.4741 , it is 0.3819 for the latter. Moreover, when wages rise, efficient producers immediately reduce labor input, but the response of labor input to a change in wages is not significant for inefficient producers. The short run wage elasticity of efficient producers is -0.8627 , but the long run wage elasticity is -1.8197; thus, large labor adjustments occur over the longer term. In contrast, inefficient producers do not make any adjustments of labor input in either the short or long run even if there is a change in wages.

When it comes to the adjustment speed for materials input, the adjustment speed of the efficient producers (0.6005) exceeds the speed of the inefficient producers (0.3410). However, inefficient producers significantly change materials input in response to changes in materials prices; there is no significant response of materials input by efficient producers in response to changes in the materials price.

As far as capital stock is concerned, the adjustment speed of inefficient producers (0.6036) is faster than that of efficient producers (0.5205). In addition, the own elasticity with respect to the rental price of capital for inefficient and efficient producers is -1.0701 and -1.0522 , respectively, and there is negligible difference between the two. Therefore, when the rental price of capital rises, rice producers reduce capital demand in the short run, irrespective of efficiency; however, the effect of the reduction in capital by inefficient producers is much larger in the long run.

\section{Determinants of Arable Land Utilization as Rice Production}

The preceding section analyzed the efficiency of rice production when the factor demand other than land is adjusted. This section conducts an econometric analysis of the determinants of the arable land utilization as rice production by dividing the producers into efficient and inefficient group. The determinants of the arable land utilized as rice production is intimately related to the decision to switch to the production of other crops, and it is also important to note that it could be affected by the governmental policies on rice production adjustment. Suppose that efficient rice producers switch from rice cultivation to other crops, and rice production may end up in the hands of inefficient producers. Then it would be costlier to produce rice of a high quality. Therefore, analyzing the determinants of the arable land utilization as rice cultivation from the standpoint of efficiency may have important policy implications. 
We assume that the proportion of arable land used for rice production is determined by the economic circumstances of rice producers in the previous year. The estimated equation is specified as follows:

$$
\begin{aligned}
& \left(\frac{L}{T L}\right)_{i t}=a_{0}+a_{1}\left(\frac{Y}{L}\right)_{i, t-1}+a_{2} F R G_{i, t-1}+a_{3} P_{A R T A_{i, t-1}}+a_{4} P A R T B_{i, t-1} \\
& +a_{5} \text { PARTC }_{i, t-1}+a_{6} \text { DEBT }_{i, t-1}+a_{7} S A K U_{i, t-1}+a_{8} H O B A V S_{i, t-1} \\
& +a_{9} H_{O B A S} S_{i, t-1}+a_{10} H O B A M_{i, t-1}+a_{11} H O B A L_{i, t-1}+a_{12} L I C_{i, t-1}+\mu_{i}+v_{i t}
\end{aligned}
$$

where $L_{i t}$ : area planted with rice

$T L_{i t}$ : total arable land

$Y_{i t}$ : rice harvest

$F R G_{i, t}$ : number of parcels

$P A R T A_{i, t}$ : dummy variable that takes 1 when a producer participates cultivation accords and 0 otherwise

PARTB $_{i, t}$ : dummy variable that takes 1 when a producer participates joint utilization and 0 otherwise

PARTC $_{i, t}$ : dummy variable that takes 1 when a producer has consignment contract and 0 otherwise

$D E B T_{i, t}$ : outstanding loan balance per $10 \mathrm{a}$

$S A K U_{i, t}$ : crop prospects relative to normal year

$H_{O B A V}, t$ : proportion of farm area not disposed of or in lots of less than 10 a

$H O B A S_{i, t}$ : proportion of farm area in lots of more than or equal 10 a and less than 20 a

$H O B A M_{i, t}$ : proportion of farm area in lots of more than or equal $20 \mathrm{a}$ and less than $30 \mathrm{a}$

$H O B A L_{i, t}$ : proportion of farm area in lots of more than or equal 30 a and less than $50 \mathrm{a}$

$L I C_{i, t-1}$ : dummy variable that takes 1 for certified farmers and 0 otherwise

$\mu_{i}$ : producer-specific effect

$v_{i t}$ : disturbance term 
The determinants of arable land utilized for rice production can be divided into three groups. The first group is associated with the performance of producers in the previous year. Outstanding loan balance, crop prospects relative to normal year and the land productivity fall under this group. The second is related to the attributes of the fields held by producers. The number of parcels of the fields and the area distribution of the farm plots fall under this group. The participation of farmers in agricultural production organizations, such as cultivation accords, joint utilization, and consignment, and the dummy variable of certified farmers, fall under the third group.

The producers were divided into an efficient and inefficient producer group based on the efficiency indices for production, and equation (12) was estimated for these groups. The estimation method is a random-effect model that is compatible with the estimation methods adopted in the preceding sections. Table 10 shows the estimation results.

As for the effects of the performance of producers on the arable land utilization for rice production, it was observed that if the land productivity was higher and the crop prospects were worse in the previous year, irrespective of efficiency, then the proportion of arable land used for rice production increased. Moreover, this effect was larger for inefficient producers.

In terms of the attributes of the fields, there is a tendency for arable land utilization for rice cultivation to be reduced more by producers that have a great deal of farmland in small plots. In particular, these effects are larger for efficient producers. The effect of the proportion of farm area that is undisposed or in micro plots of less than 10 are on arable land utilization for rice production is largest; these effects gradually decline as the plots grow larger. Compared to this, the effect of the proportion of farm area that is undisposed or in micro plots of less than 10 are is much smaller in the case of inefficient producers. Consequently, more efficient rice producer tends to switch from rice grown on a small plot to the other crops, and thus his land employed for rice cultivation will be concentrated in relatively large-scale fields.

Among the variables related to the organization form of rice producers, being a certified farmer significantly reduces the arable land used for rice production. This result is consistent with the findings of Saito and Ohashi (2015), which showed that certified farmers tend to switch to crops other than rice. Our results confirm their findings and further show that the more efficient a certified farmer is, the larger this effect will be. If a certified farmer was efficient in the previous year, he will reduce arable land utilization rate for rice production by $6.5 \%$, while the extent of the reduction by inefficient certified farmers is only $3.1 \%$. The negative effect of being certified 
farmer on arable land utilization for rice production may reflect the fact that cooperation in production adjustment for rice was a requirement at the stage of applying for certified farmers prior to 2009; however, since this effect is greater when the farmer is more efficient, it suggests that productivity of rice production will decline as the proportion of arable land used for rice production declines, which is the opposite of what was intended by policymakers.

\section{Concluding Remarks}

This study conducts an empirical analysis on the behavior of Japanese rice producers from the viewpoint of efficiency of production by using the panel data from the Rice Production Cost Statistics by the Ministry of Agriculture, Forestry and Fisheries. The stochastic frontier production function, which comprises four production factors (land, labor, capital stock, and materials), was estimated, and the inefficiency indices of production were calculated. This information was used in identifying the efficient and inefficient rice producers. Then the factor demand and the characteristics of the arable land utilization for rice production were compared between the efficient and inefficient rice producers. With regard to factor demand, we found that inefficient rice producers do not make any adjustments in employment in the short or long run even if there is a change in the wages. In addition, it was found that efficient rice producers who hold a large amount of the farms partitioned into small plots aim at increasing productivity by reducing the arable land utilization for rice production. Moreover, these effects are greater for an efficient certified farmer.

In a situation wherein the demand for rice is decreasing as a secular trend, the government has promoted the policy of switching from cultivation of rice as a staple food to other crops to resolve chronic oversupply of rice. For the successful implementation of the policy on adjusting the production of rice, the efficient producers should engage in the production of rice to improve productivity, while the inefficient producers should aim at switching rapidly from cultivation of rice as a staple food to rice for feed and other crops. However, in reality the efficient certified farmers tend to promote a shift from rice production. If this trend continues, there might be a further decline in the productivity of rice production. In order to avoid such a situation, it is imperative to design an agricultural system that gives incentives to efficient rice producers to expand rice cultivation, and inefficient producers to withdraw from rice cultivation and switch to other crops. 
References

Aigner, D., K. Lovell, and P. Schmidt (1977). "Formulation and Estimation of Stochastic Frontier Production Function Models,” Journal of Econometrics, 6, pp. 21-37.

Battese, G., and T. Coelli (1988). "Prediction of Firm-level Technical Efficiencies with a Generalized Frontier Production Function and Panel Data,” Journal of Econometrics, 38, pp. 387-399.

Battese, G., and T. Coelli (1992). "Frontier Production Functions, Technical Efficiency and Panel Data: With Application to Paddy Farmers in India,” Journal of Productivity Analysis, 3, pp. 153-169.

Hayami, Y. and T. Kawagoe (1989). "Farm Mechanization, Scale Economies and Polarization: The Japanese experience" Journal of Development Economics, 31 pp. 221-239.

Jondrow, J., K. Lovell, I. Materov, and P. Schmidt (1982). “On the Estimation of Technical Inefficiency in the Stochastic Frontier Production Function Model,” Journal of Econometrics, 19, pp. 233-238.

Kako, T. (1979) . "Inasaku niokeru Kibo no Keisoku (Estimation of Scale Economies in Rice Production),” The Economic Studies Quarterly, Vol.30, No.2, pp. 160-171 (in Japanese).

Kawasaki, K. (2010). “The Costs and Benefits of Land Fragmentation of Rice Farms in Japan,” The Australian Journal of Agricultural and Resource Economics, 54, pp.509526.

Meeusen,W., and J. van den Broeck (1977). "Efficiency Estimation from Cobb-Douglas Production Functions with Composed Error,” International Economic Review, 18, pp. 435-444.

Pitt, M., and L. Lee (1981). “The Measurement and Sources of Technical Inefficiency in the Indonesian Weaving Industry,” Journal of Development Economics,9, pp. 43-64.

Saito, K., H. Ohashi, and K. Nishimura (2010). “Syuraku Eino ga Inasaku no Seisan oyobi Hiyo ni Ataeru Eikyo - Daikibo Inasaku Keiei no Simulation Bunseki (The Effects of Community Farming on Production and Cost of Rice Cultivation - A Simulation Analysis of Large-scale Rice Farming-), RIETI Discussion Paper Series 10-J-009 (in Japanese). 
Saito, K. and H. Ohashi (2015). “Inasaku Seisan Chosei ni kansuru Simulation Bunseki - Tensaku oyobi Solar Sharing nikansuru Seisaku Koka (A Simulation Analysis on Rice Production Adjustment: Policy Effects on Switching Crops and Solar Sharing), RIETI Discussion Paper Series 15-J-055 (in Japanese). 
Table 1 Sample Distribution by Prefecture

\begin{tabular}{|c|c|c|c|}
\hline region & prefecture & $\begin{array}{l}\text { number of } \\
\text { observations }\end{array}$ & $\begin{array}{l}\text { number of } \\
\text { observations by } \\
\text { region }\end{array}$ \\
\hline Hokkaido & Hokkaido & 543 & 543 \\
\hline Tohoku & $\begin{array}{l}\text { Aomori } \\
\text { Iwate } \\
\text { Miyagi } \\
\text { Akita } \\
\text { Yamagata } \\
\text { Fukushima }\end{array}$ & $\begin{array}{l}190 \\
195 \\
255 \\
338 \\
261 \\
268\end{array}$ & 1507 \\
\hline $\begin{array}{l}\text { North Kanto } \\
\text { \& Koshin }\end{array}$ & $\begin{array}{l}\text { Ibaraki } \\
\text { Tochigi } \\
\text { Gunma } \\
\text { Yamanashi } \\
\text { Nagano }\end{array}$ & $\begin{array}{r}234 \\
242 \\
48 \\
10 \\
98 \\
\end{array}$ & 632 \\
\hline South Kanto & $\begin{array}{l}\text { Saitama } \\
\text { Chiba } \\
\text { Tokyo } \\
\text { Kanagawa } \\
\end{array}$ & $\begin{array}{r}110 \\
202 \\
0 \\
8 \\
\end{array}$ & 320 \\
\hline Hokuriku & $\begin{array}{l}\text { Niigata } \\
\text { Toyama } \\
\text { Ishikawa } \\
\text { Fukui } \\
\end{array}$ & $\begin{array}{r}402 \\
114 \\
83 \\
86 \\
\end{array}$ & 685 \\
\hline Tokai & $\begin{array}{l}\text { Gifu } \\
\text { Shizuoka } \\
\text { Aichi } \\
\text { Mie } \\
\end{array}$ & $\begin{array}{r}51 \\
46 \\
88 \\
112 \\
\end{array}$ & 297 \\
\hline Kinki & $\begin{array}{l}\text { Shiga } \\
\text { Kyoto } \\
\text { Osaka } \\
\text { Hyogo } \\
\text { Nara } \\
\text { Wakayama } \\
\end{array}$ & $\begin{array}{r}114 \\
46 \\
14 \\
112 \\
19 \\
20 \\
\end{array}$ & 325 \\
\hline Cyugoku & $\begin{array}{l}\text { Tottori } \\
\text { Shimane } \\
\text { Okayama } \\
\text { Hiroshima } \\
\text { Yamaguchi }\end{array}$ & $\begin{array}{r}37 \\
60 \\
112 \\
66 \\
65\end{array}$ & 340 \\
\hline Shikoku & $\begin{array}{l}\text { Tokushima } \\
\text { Kagawa } \\
\text { Ehime } \\
\text { Kochi } \\
\end{array}$ & $\begin{array}{l}54 \\
64 \\
63 \\
45 \\
\end{array}$ & 226 \\
\hline Kyusyu & $\begin{array}{l}\text { Fukuoka } \\
\text { Saga } \\
\text { Nagasaki } \\
\text { Kumamoto } \\
\text { Oita } \\
\text { Miyazaki } \\
\text { Kagoshima } \\
\text { Okinaawa }\end{array}$ & $\begin{array}{r}142 \\
88 \\
44 \\
130 \\
76 \\
52 \\
46 \\
0 \\
\end{array}$ & 578 \\
\hline & total & 5453 & 5453 \\
\hline
\end{tabular}

Source: Ministry of Agriculture, Forestry and Fisheries,

Rice Production Cost Statistics 
Table 2 Descriptive Statistics of Major Variables

\begin{tabular}{|c|c|c|c|}
\hline & mean & median & $\begin{array}{l}\text { standard } \\
\text { deviation }\end{array}$ \\
\hline Yield of rice $(\mathrm{kg})$ & 21891 & 10290 & $\overline{31021}$ \\
\hline Area planted for rice production (a) & 416.0 & 199.0 & 578.6 \\
\hline Labor input (hours) & 816.2 & 515.0 & 914.7 \\
\hline Capital stock (ten thousand yen) 1) & 400.3 & 196.5 & 583.7 \\
\hline Material input (ten thousand yen) ${ }^{2}$ ) & 100.7 & 49.3 & 139.3 \\
\hline Land productivity (kg/a.) & 51.4 & 51.7 & 7.4 \\
\hline Labor productivity (kg/hour) & 23.5 & 21.0 & 12.8 \\
\hline Capital productivity (kg/ten thousand yen) & 291.5 & 60.0 & 5276.9 \\
\hline Arable land utilization as rice production (\%) & 74.2 & 75.6 & 18.2 \\
\hline $\begin{array}{l}\text { Proportion of farm area not disposed of or in lots of } \\
\text { less than } 10 \mathrm{a}(\%)\end{array}$ & 17.4 & 5.1 & 26.8 \\
\hline $\begin{array}{l}\text { Proportion of farm area in lots more than or equal } 10 \\
\text { a and less than } 20 \mathrm{a} \mathrm{( \% )}\end{array}$ & 27.0 & 18.6 & 28.2 \\
\hline $\begin{array}{l}\text { Proportion of farm area in lots more than or equal } 20 \\
\text { a and less than } 30 \mathrm{a}(\%)\end{array}$ & 27.0 & 18.6 & 29.0 \\
\hline $\begin{array}{l}\text { Proportion of farm area in lots more than or equal } 30 \\
\text { a and less than } 50 \mathrm{a} \mathrm{( \% )}\end{array}$ & 18.6 & 0.0 & 25.7 \\
\hline $\begin{array}{l}\text { Proportion of farm area in lots more than or equal } 50 \\
\text { a (\%) }\end{array}$ & 10.0 & 0.0 & 23.2 \\
\hline
\end{tabular}

Notes: 1), 2) real values in 2010 price

Source: Ministry of Agriculture, Forestry and Fisheries, Rice Production Cost Statistic: 
Table 3 Estimation Results of Stochastic Frontier Production Function (1)

\begin{tabular}{|c|c|c|c|c|c|c|c|c|}
\hline \multirow[b]{2}{*}{$\ln \mathrm{N}$} & \multicolumn{2}{|c|}{$\begin{array}{l}(1) \\
\text { haf-normal }\end{array}$} & \multicolumn{2}{|c|}{ (2) } & \multicolumn{4}{|c|}{$\begin{array}{l}(3) \\
\text { truncated-normal }\end{array}$} \\
\hline & $\begin{array}{l}0.0141 \\
(2.46)\end{array}$ & $* *$ & $\begin{array}{c}-0.0854 \\
(-0.55)\end{array}$ & & $\begin{array}{l}0.0141 \\
(2.44)\end{array}$ & $* *$ & $\begin{array}{c}-0.0852 \\
(-0.55)\end{array}$ & \\
\hline $\ln \mathrm{K}$ & $\begin{array}{l}0.0048 \\
(2.51)\end{array}$ & $* *$ & $\begin{array}{l}-0.1589 \\
(-2.96)\end{array}$ & $* * *$ & $\begin{array}{c}0.0048 \\
(2.51)\end{array}$ & $* *$ & $\begin{array}{l}-0.1586 \\
(-2.97)\end{array}$ & $* * *$ \\
\hline $\operatorname{lnL}$ & $\begin{array}{c}0.9397 \\
(115.56)\end{array}$ & $* * *$ & $\begin{array}{l}1.0582 \\
(3.84)\end{array}$ & $* * *$ & $\begin{array}{c}0.9398 \\
(115.14)\end{array}$ & $* * *$ & $\begin{array}{l}1.0551 \\
(3.90)\end{array}$ & $* * *$ \\
\hline $\ln \mathrm{M}$ & $\begin{array}{l}0.0567 \\
(6.64)\end{array}$ & $* * *$ & $\begin{array}{l}0.2854 \\
(0.90)\end{array}$ & & $\begin{array}{l}0.0568 \\
(6.63)\end{array}$ & $* * *$ & $\begin{array}{c}0.2879 \\
(0.93)\end{array}$ & \\
\hline$(\operatorname{lnN})^{2}$ & & & $\begin{array}{l}0.0047 \\
(0.55)\end{array}$ & & & & $\begin{array}{c}0.0047 \\
(0.55)\end{array}$ & \\
\hline$(\operatorname{lnN})(\ln K)$ & & & $\begin{array}{c}0.0044 \\
(1.10)\end{array}$ & & & & $\begin{array}{c}0.0046 \\
(1.13)\end{array}$ & \\
\hline$(\operatorname{lnN})(\operatorname{lnL})$ & & & $\begin{array}{r}-0.0047 \\
(-0.26)\end{array}$ & & & & $\begin{array}{l}-0.0048 \\
(-0.27)\end{array}$ & \\
\hline$(\operatorname{lnN})(\operatorname{lnM})$ & & & $\begin{array}{l}0.0005 \\
(0.03)\end{array}$ & & & & $\begin{array}{c}0.0003 \\
(0.02)\end{array}$ & \\
\hline$(\ln K)^{2}$ & & & $\begin{array}{l}0.0005 \\
(0.69)\end{array}$ & & & & $\begin{array}{c}0.0005 \\
(0.68)\end{array}$ & \\
\hline$(\operatorname{lnK})(\ln M)$ & & & $\begin{array}{c}0.0166 \\
(2.58)\end{array}$ & $* * *$ & & & $\begin{array}{c}0.0166 \\
(2.59)\end{array}$ & $* * *$ \\
\hline$(\operatorname{lnK})(\operatorname{lnL})$ & & & $\begin{array}{l}-0.0176 \\
(-2.90)\end{array}$ & $* * *$ & & & $\begin{array}{l}-0.0177 \\
(-2.92)\end{array}$ & $* * *$ \\
\hline$(\operatorname{lnL})^{2}$ & & & $\begin{array}{c}0.0113 \\
(0.67)\end{array}$ & & & & $\begin{array}{c}0.0111 \\
(0.67)\end{array}$ & \\
\hline$(\operatorname{lnL})(\ln M)$ & & & $\begin{array}{l}0.0033 \\
(0.10)\end{array}$ & & & & $\begin{array}{c}0.0038 \\
(0.11)\end{array}$ & \\
\hline$(\ln M)^{2}$ & & & $\begin{array}{l}-0.0187 \\
(-0.92)\end{array}$ & & & & $\begin{array}{l}-0.0188 \\
(-0.94)\end{array}$ & \\
\hline Tohoku & $\begin{array}{l}0.0093 \\
(1.00)\end{array}$ & & $\begin{array}{l}0.0082 \\
(0.87)\end{array}$ & & $\begin{array}{l}0.0095 \\
(1.02)\end{array}$ & & $\begin{array}{c}0.0084 \\
(0.88)\end{array}$ & \\
\hline North Kanto \& Koshin & $\begin{array}{l}-0.0078 \\
(-0.68)\end{array}$ & & $\begin{array}{l}-0.0116 \\
(-1.00)\end{array}$ & & $\begin{array}{l}-0.0075 \\
(-0.66)\end{array}$ & & $\begin{array}{l}-0.0115 \\
(-0.98)\end{array}$ & \\
\hline South Kanto & $\begin{array}{l}-0.0553 \\
(-4.15)\end{array}$ & $* * *$ & $\begin{array}{l}-0.0568 \\
(-4.20)\end{array}$ & $* * *$ & $\begin{array}{l}-0.0555 \\
(-4.15)\end{array}$ & $* * *$ & $\begin{array}{r}-0.0569 \\
(-4.20)\end{array}$ & $* * *$ \\
\hline Hokuriku & $\begin{array}{l}-0.0326 \\
(-3.01)\end{array}$ & $* * *$ & $\begin{array}{r}-0.0339 \\
(-3.05)\end{array}$ & $* * *$ & $\begin{array}{l}-0.0324 \\
(-2.97)\end{array}$ & $* * *$ & $\begin{array}{l}-0.0337 \\
(-3.03)\end{array}$ & $* * *$ \\
\hline Tokai & $\begin{array}{l}-0.0894 \\
(-6.56)\end{array}$ & $* * *$ & $\begin{array}{r}-0.0903 \\
(-6.62)\end{array}$ & $* * *$ & $\begin{array}{l}-0.0896 \\
(-6.54)\end{array}$ & $* * *$ & $\begin{array}{l}-0.0905 \\
(-6.61)\end{array}$ & $* * *$ \\
\hline Kinki & $\begin{array}{l}-0.1021 \\
(-7.65)\end{array}$ & $* * *$ & $\begin{array}{l}-0.1055 \\
(-7.83)\end{array}$ & $* * *$ & $\begin{array}{l}-0.1015 \\
(-7.52)\end{array}$ & $* * *$ & $\begin{array}{l}-0.105 \\
(-7.72)\end{array}$ & $* * *$ \\
\hline Cyugoku & $\begin{array}{l}-0.0733 \\
(-5.68)\end{array}$ & $* * *$ & $\begin{array}{l}-0.076 \\
(-5.83)\end{array}$ & $* * *$ & $\begin{array}{l}-0.0737 \\
(-5.68)\end{array}$ & $* * *$ & $\begin{array}{l}-0.0763 \\
(-5.82)\end{array}$ & $* * *$ \\
\hline Shikoku & $\begin{array}{l}-0.0927 \\
(-6.30)\end{array}$ & $* * *$ & $\begin{array}{l}-0.0951 \\
(-6.42)\end{array}$ & $* * *$ & $\begin{array}{l}-0.0927 \\
(-6.28)\end{array}$ & $* * *$ & $\begin{array}{l}-0.0951 \\
(-6.40)\end{array}$ & $* * *$ \\
\hline Kyusyu & $\begin{array}{l}-0.1294 \\
(-10.97)\end{array}$ & $* * *$ & $\begin{array}{l}-0.1324 \\
(-11.09)\end{array}$ & $* * *$ & $\begin{array}{l}-0.1294 \\
(-10.91)\end{array}$ & $* * *$ & $\begin{array}{l}-0.1324 \\
(-11.05)\end{array}$ & $* * *$ \\
\hline Constant term & $\begin{array}{l}3.5602 \\
(49.90)\end{array}$ & $* * *$ & $\begin{array}{l}3.2245 \\
(2.50)\end{array}$ & $* * *$ & $\begin{array}{l}3.5612 \\
(49.74)\end{array}$ & $* * *$ & $\begin{array}{l}3.2142 \\
(2.54)\end{array}$ & $* * *$ \\
\hline$\mu$ & & & & & $\begin{array}{l}0.0186 \\
(0.47)\end{array}$ & & $\begin{array}{c}0.0149 \\
(0.37)\end{array}$ & \\
\hline$\sigma_{\mathrm{u}}$ & $\begin{array}{l}0.1788 \\
(42.24)\end{array}$ & $* * *$ & $\begin{array}{l}0.1778 \\
(42.03)\end{array}$ & $* * *$ & $\begin{array}{l}0.0298 \\
(6.37)\end{array}$ & $* * *$ & $\begin{array}{l}0.0299 \\
(6.23)\end{array}$ & $* * *$ \\
\hline$\sigma_{\mathrm{v}}$ & $\begin{array}{l}0.0926 \\
(84.86) \\
\end{array}$ & *** & $\begin{array}{l}0.0926 \\
(84.75) \\
\end{array}$ & $* * *$ & $\begin{array}{r}0.0086 \\
(41.98) \\
\end{array}$ & $* * *$ & $\begin{array}{l}0.0086 \\
(41.92) \\
\end{array}$ & $* * *$ \\
\hline Number of observations & 5408 & & 5408 & & 5408 & & 5408 & \\
\hline
\end{tabular}

Notes: The coefficient estimates of year dummies are suppressed. 
Table 4

Comparison of Production Inefficiency Indices

\begin{tabular}{|ll|rrr|}
\hline production function & $\begin{array}{c}\text { probability distribution } \\
\text { of inefficiency }\end{array}$ & mean & median & \multicolumn{1}{c|}{$\begin{array}{c}\text { standard } \\
\text { deviation }\end{array}$} \\
\hline Cobb-Douglas & Half-normal & 0.1102 & 0.0797 & 0.0867 \\
Translog & Half-normal & 0.1098 & 0.0800 & 0.0864 \\
Cobb-Douglas & Truncated normal & 0.1418 & 0.1211 & 0.0946 \\
Translog & Truncated normal & 0.1407 & 0.1192 & 0.0941 \\
\hline
\end{tabular}


Table 5

Estimation Results of Stochastic Frontier Production Function (2)

\begin{tabular}{|c|c|c|c|c|}
\hline & (1) & & (2) & \\
\hline $\operatorname{lnN}$ & $\begin{array}{l}0.0141 \\
(2.44)\end{array}$ & $* *$ & $\begin{array}{c}-0.0855 \\
(-0.55)\end{array}$ & \\
\hline $\ln K$ & $\begin{array}{l}0.0048 \\
(2.52)\end{array}$ & $* *$ & $\begin{array}{c}-0.1584 \\
(-2.96)\end{array}$ & $* * *$ \\
\hline $\ln L$ & $\begin{array}{c}0.9398 \\
(115.14)\end{array}$ & $* * *$ & $\begin{array}{l}1.0534 \\
(3.89)\end{array}$ & $* * *$ \\
\hline $\ln \mathrm{M}$ & $\begin{array}{c}0.0568 \\
(6.63)\end{array}$ & $* * *$ & $\begin{array}{c}0.29 \\
(0.93)\end{array}$ & \\
\hline$(\operatorname{lnN})^{2}$ & & & $\begin{array}{l}0.0047 \\
(0.55)\end{array}$ & \\
\hline$(\ln N)(\ln K)$ & & & $\begin{array}{l}0.0046 \\
(1.14)\end{array}$ & \\
\hline$(\ln N)(\operatorname{lnL})$ & & & $\begin{array}{c}-0.0047 \\
(-0.26)\end{array}$ & \\
\hline$(\ln N)(\ln M)$ & & & $\begin{array}{c}0.0003 \\
(0.02)\end{array}$ & \\
\hline$(\operatorname{lnK})^{2}$ & & & $\begin{array}{l}0.0005 \\
(0.68)\end{array}$ & \\
\hline$(\operatorname{lnK})(\ln M)$ & & & $\begin{array}{l}0.0165 \\
(2.58)\end{array}$ & $* * *$ \\
\hline$(\operatorname{lnK})(\operatorname{lnL})$ & & & $\begin{array}{c}-0.0177 \\
(-2.92)\end{array}$ & $* * *$ \\
\hline$(\operatorname{lnL})^{2}$ & & & $\begin{array}{l}0.011 \\
(0.66)\end{array}$ & \\
\hline$(\operatorname{lnL})(\ln M)$ & & & $\begin{array}{l}0.004 \\
(0.12)\end{array}$ & \\
\hline$(\ln M)^{2}$ & & & $\begin{array}{c}-0.0189 \\
(-0.94)\end{array}$ & \\
\hline Tohoku & $\begin{array}{c}0.0095 \\
(1.01)\end{array}$ & & $\begin{array}{c}0.0082 \\
(0.86)\end{array}$ & \\
\hline North Kanto \& Koshin & $\begin{array}{l}-0.0075 \\
(-0.66)\end{array}$ & & $\begin{array}{l}-0.0115 \\
(-0.98)\end{array}$ & \\
\hline South Kanto & $\begin{array}{l}-0.0556 \\
(-4.15)\end{array}$ & $* * *$ & $\begin{array}{c}-0.0571 \\
(-4.20)\end{array}$ & $* * *$ \\
\hline Hokuriku & $\begin{array}{l}-0.0325 \\
(-2.97)\end{array}$ & $* * *$ & $\begin{array}{c}-0.0338 \\
(-3.03)\end{array}$ & $* * *$ \\
\hline Tokai & $\begin{array}{l}-0.0895 \\
(-6.53)\end{array}$ & $* * *$ & $\begin{array}{c}-0.0904 \\
(-6.59)\end{array}$ & $* * *$ \\
\hline Kinki & $\begin{array}{l}-0.1016 \\
(-7.52)\end{array}$ & $* * *$ & $\begin{array}{c}-0.1052 \\
(-7.73)\end{array}$ & $* * *$ \\
\hline Cyugoku & $\begin{array}{l}-0.0739 \\
(-5.67)\end{array}$ & $* * *$ & $\begin{array}{c}-0.0765 \\
(-5.82)\end{array}$ & $* * *$ \\
\hline Shikoku & $\begin{array}{l}-0.0928 \\
(-6.28)\end{array}$ & $* * *$ & $\begin{array}{c}-0.0953 \\
(-6.41)\end{array}$ & $* * *$ \\
\hline Kyusyu & $\begin{array}{l}-0.1295 \\
(-10.91)\end{array}$ & $* * *$ & $\begin{array}{l}-0.1325 \\
(-11.05)\end{array}$ & $* * *$ \\
\hline Constant term & $\begin{array}{l}3.56142 \\
(49.74)\end{array}$ & $* * *$ & $\begin{array}{c}3.2039 \\
(2.53)\end{array}$ & $* * *$ \\
\hline$\mu$ & $\begin{array}{c}0.0179 \\
(0.45)\end{array}$ & & $\begin{array}{c}0.0138 \\
(0.33)\end{array}$ & \\
\hline$\eta$ & $\begin{array}{c}0.0011 \\
(0.15)\end{array}$ & & $\begin{array}{c}0.0017 \\
(0.24)\end{array}$ & \\
\hline$\sigma_{\mathrm{u}}$ & $\begin{array}{c}0.03 \\
(6.19)\end{array}$ & $* * *$ & $\begin{array}{l}0.0302 \\
(42.03)\end{array}$ & $* * *$ \\
\hline$\sigma_{\mathrm{v}}$ & $\begin{array}{l}0.0086 \\
(41.98) \\
\end{array}$ & $* * *$ & $\begin{array}{l}0.0086 \\
(41.90) \\
\end{array}$ & $* * *$ \\
\hline Number of ol & 5408 & & 5408 & \\
\hline
\end{tabular}

Notes: The coefficient estimates of year dummies are suppressed. 
Table 6 Comparison of Characteristics between Efficient and Inefficient Rice Producer:

\begin{tabular}{|l|ccc|}
\hline & $\begin{array}{c}\text { inefficient } \\
\text { producers }\end{array}$ & $\begin{array}{c}\text { efficient } \\
\text { producers }\end{array}$ & $\begin{array}{c}\text { test statistics of } \\
\text { mean difference }\end{array}$ \\
\hline Number of parcels & 4.5 & 4.25 & $2.12^{* *}$ \\
Area planted for rice production (a) & 408.6 & 423.5 & -0.95 \\
Income per 10 a (yen) & 13620.6 & 24126.6 & $-8.71^{* * *}$ \\
Outstanding loan balance per 10 a (yen ) & 15854.5 & 11702.2 & $3.99^{* * *}$ \\
Land productivity (kg/a) & 47.7 & 55.1 & $-42.9^{* * *}$ \\
Labor productivity (kg/hour) & 142.1 & 442.7 & $-2.10^{* *}$ \\
Capital productivity (kg/ten thousand yen) & 21.9 & 25.1 & $-9.25^{* * *}$ \\
Arable land utilization as rice production (\%) & 73.5 & 74.9 & $-2.69^{* * *}$ \\
Net receipt of mutual aid money per 10 a (yen) & -135.5 & -376 & $3.41^{* * *}$ \\
Proportion of farm area not disposed of or in lots of & 18.7 & 16.1 & $3.58^{* * *}$ \\
less than 10 a (\%) & & & $3.70^{* * *}$ \\
Proportion of farm area in lots more than or equal 10 a & 28.4 & 25.6 & -0.74 \\
and less than 20 a (\%) & & 27.3 & $-1.96^{*}$ \\
Proportion of farm area in lots more than or equal 20 a & 26.8 & 19.2 & $-5.55^{* * *}$ \\
and less than 30 a (\%) & & & $4.09^{* * *}$ \\
Proportion of farm area in lots more than or equal 30 a & 17.9 & 11.7 & 0.73 \\
and less than 50 a (\%) & & 44.5 & \\
Proportion of farm area in lots more than or equal 50 a & 8.2 & 217.5 & \\
(\%) & 50 & 218.2 & \\
Proportion of certified farmers (\%) & & & \\
Price of the harvested rice per kg (yen ) & & & \\
\hline
\end{tabular}

Notes: ${ }^{*},{ }^{* *},{ }^{* * *}$ significant at $10 \%, 5 \%, 1 \%$ level, respectively 
Table 7 Estimation Results of Factor Demand Function with Inefficiency

\begin{tabular}{|c|c|c|c|c|c|c|}
\hline & $\ln K$ & & $\ln \mathrm{N}$ & & $\ln M$ & \\
\hline $\ln \left(\mathrm{p}_{\mathrm{K}} / \mathrm{p}\right)$ & $\begin{array}{c}-1.1638 \\
(-164.76)\end{array}$ & $* *$ & $\begin{array}{l}-0.0189 \\
(-4.05)\end{array}$ & $* * *$ & $\begin{array}{c}-0.0187 \\
(-4.88)\end{array}$ & $* * *$ \\
\hline $\ln (\mathrm{w} / \mathrm{p})$ & $\begin{array}{c}0.0684 \\
(1.13)\end{array}$ & & $\begin{array}{l}-0.336 \\
(-9.15)\end{array}$ & $* * *$ & $\begin{array}{c}-0.0495 \\
(-1.63)\end{array}$ & \\
\hline $\ln \left(\mathrm{p}_{\mathrm{M}} / \mathrm{p}\right)$ & $\begin{array}{l}1.1065 \\
(14.51)\end{array}$ & $* * *$ & $\begin{array}{c}0.2989 \\
(6.76)\end{array}$ & $* * *$ & $\begin{array}{c}-0.0627 \\
(-1.67)\end{array}$ & $*$ \\
\hline $\ln \mathrm{L}$ & $\begin{array}{l}0.6551 \\
(85.97)\end{array}$ & $* * *$ & $\begin{array}{c}0.6955 \\
(111.87)\end{array}$ & $* * *$ & $\begin{array}{c}0.8976 \\
(235.56)\end{array}$ & $* * *$ \\
\hline Tohoku & $\begin{array}{c}-0.1542 \\
(-4.34)\end{array}$ & $* * *$ & $\begin{array}{c}-0.1679 \\
(-5.90)\end{array}$ & $* * *$ & $\begin{array}{c}0.0074 \\
(0.38)\end{array}$ & \\
\hline North Kanto \& Koshin & $\begin{array}{c}-0.0692 \\
(-1.65)\end{array}$ & $*$ & $\begin{array}{c}-0.0031 \\
(-0.09)\end{array}$ & & $\begin{array}{c}-0.0667 \\
(-2.94)\end{array}$ & $* * *$ \\
\hline South Kanto & $\begin{array}{c}-0.0343 \\
(-0.67)\end{array}$ & & $\begin{array}{c}-0.1597 \\
(-4.09)\end{array}$ & $* * *$ & $\begin{array}{c}-0.2334 \\
(-8.51)\end{array}$ & $* * *$ \\
\hline Hokuriku & $\begin{array}{c}-0.0612 \\
(-1.56)\end{array}$ & & $\begin{array}{l}-0.049 \\
(-1.43)\end{array}$ & & $\begin{array}{c}-0.0098 \\
(-0.46)\end{array}$ & \\
\hline Tokai & $\begin{array}{c}-0.0582 \\
(-1.18)\end{array}$ & & $\begin{array}{l}0.0983 \\
(2.52)\end{array}$ & $* *$ & $\begin{array}{c}-0.0238 \\
(-0.94)\end{array}$ & \\
\hline Kinki & $\begin{array}{c}-0.0068 \\
(-0.14)\end{array}$ & & $\begin{array}{l}-0.085 \\
(-2.06)\end{array}$ & $* *$ & $\begin{array}{c}0.0208 \\
(0.76)\end{array}$ & \\
\hline Cyugoku & $\begin{array}{c}-0.1345 \\
(-2.79)\end{array}$ & $* * *$ & $\begin{array}{c}0.0655 \\
(1.61)\end{array}$ & & $\begin{array}{l}0.0557 \\
(2.12)\end{array}$ & $* *$ \\
\hline Shikoku & $\begin{array}{c}-0.0408 \\
(-0.75)\end{array}$ & & $\begin{array}{c}-0.0707 \\
(-1.53)\end{array}$ & & $\begin{array}{c}-0.0433 \\
(-1.52)\end{array}$ & \\
\hline Kyusyu & $\begin{array}{c}-0.1954 \\
(-4.39)\end{array}$ & $* * *$ & $\begin{array}{c}-0.2171 \\
(-6.11)\end{array}$ & $* * *$ & $\begin{array}{c}-0.1274 \\
(-5.31)\end{array}$ & $* * *$ \\
\hline Constant term & $\begin{array}{l}10.463 \\
(20.38)\end{array}$ & $* * *$ & $\begin{array}{l}5.4731 \\
(17.94)\end{array}$ & $* * *$ & $\begin{array}{l}8.4112 \\
(32.98)\end{array}$ & $* * *$ \\
\hline$\sigma_{\mathrm{u}}$ & $\begin{array}{l}0.7347 \\
(46.16)\end{array}$ & $* * *$ & $\begin{array}{l}0.8126 \\
(50.77)\end{array}$ & $* * *$ & $\begin{array}{l}0.4317 \\
(47.20)\end{array}$ & $* * *$ \\
\hline$\sigma_{\mathrm{v}}$ & $\begin{array}{r}0.2585 \\
(81.99) \\
\end{array}$ & $* * *$ & $\begin{array}{r}0.1186 \\
(77.58) \\
\end{array}$ & $* * *$ & $\begin{array}{r}0.1159 \\
(79.39) \\
\end{array}$ & $* * *$ \\
\hline Number of observations & 5408 & & 5408 & & 5408 & \\
\hline
\end{tabular}

Notes: The coefficient estimates of year dummies are suppressed. 
Table 8 Inefficient Indices of Production and Factor Demand

(1) Mean, Median and Standard Deviation

\begin{tabular}{|l|ccc|}
\hline factor demand & mean & median & $\begin{array}{c}\text { standard } \\
\text { deviation }\end{array}$ \\
\hline $\ln \mathrm{Y}$ & 0.1102 & 0.0797 & 0.0867 \\
$\ln \mathrm{K}$ & 0.4702 & 0.3769 & 0.3568 \\
$\ln \mathrm{N}$ & 0.5443 & 0.4591 & 0.3922 \\
$\ln \mathrm{M}$ & 0.2843 & 0.2334 & 0.2113 \\
\hline
\end{tabular}

(2) Correlation Coefficient

\begin{tabular}{|l|rrrr|}
\hline & $\ln \mathrm{Y}$ & $\ln \mathrm{ln}$ & $\ln \mathrm{l}$ \\
\hline $\ln \mathrm{Y}$ & 1.0000 & & & \\
$\ln \mathrm{N}$ & 0.3560 & 1.0000 & & \\
$\ln \mathrm{N}$ & 0.2396 & 0.2437 & 1.0000 & \\
$\ln \mathrm{l}$ & 0.2305 & 0.3548 & 0.4799 & 1.0000 \\
\hline
\end{tabular}


Table 9 Estimation Results of Dynamic Factor Demand Function

(1) Efficient Rice Producers

\begin{tabular}{|c|c|c|c|c|c|c|}
\hline & $\ln \mathrm{K}$ & & $\ln N$ & & $\ln M$ & \\
\hline $\ln \left(\mathrm{p}_{\mathrm{K}} / \mathrm{p}\right)$ & $\begin{array}{l}-1.0522 \\
(-15.21)\end{array}$ & $* * *$ & $\begin{array}{l}0.0019 \\
(0.06)\end{array}$ & & $\begin{array}{l}0.0081 \\
(0.23)\end{array}$ & \\
\hline $\ln (\mathrm{w} / \mathrm{p})$ & $\begin{array}{l}-0.3179 \\
(-1.27)\end{array}$ & & $\begin{array}{l}-0.8627 \\
(-3.09)\end{array}$ & $* * *$ & $\begin{array}{l}-0.4881 \\
(-2.09)\end{array}$ & $* *$ \\
\hline $\ln \left(\mathrm{p}_{\mathrm{M}} / \mathrm{p}\right)$ & $\begin{array}{l}1.679 \\
(5.72)\end{array}$ & $* * *$ & $\begin{array}{l}0.9617 \\
(2.47)\end{array}$ & $* *$ & $\begin{array}{l}0.4562 \\
(1.47)\end{array}$ & \\
\hline lagged dependent variable & $\begin{array}{c}0.4795 \\
(6.73)\end{array}$ & $* * *$ & $\begin{array}{l}0.5259 \\
(5.03)\end{array}$ & $* * *$ & $\begin{array}{l}0.3995 \\
(3.89)\end{array}$ & $* * *$ \\
\hline Constant term & $\begin{array}{c}10.8729 \\
(5.52)\end{array}$ & $* * *$ & $\begin{array}{l}9.6922 \\
(3.46)\end{array}$ & $* * *$ & $\begin{array}{c}11.2654 \\
(4.26)\end{array}$ & $* * *$ \\
\hline $\begin{array}{l}\text { Test statistics of } \\
\text { serial correlation }\end{array}$ & 0.6744 & & -0.1362 & & 0.453 & \\
\hline Number of observations & 1551 & & 1552 & & 1552 & \\
\hline
\end{tabular}

Notes: The coefficient estimates of year dummies are suppressed.
(2) Inefficient Rice Producers

\begin{tabular}{|c|c|c|c|c|c|c|}
\hline & $\ln K$ & & $\ln N$ & & $\ln M$ & \\
\hline $\ln \left(\mathrm{p}_{\mathrm{K}} / \mathrm{p}\right)$ & $\begin{array}{l}-1.0701 \\
(-26.72)\end{array}$ & $* * *$ & $\begin{array}{l}0.0855 \\
(2.54)\end{array}$ & $* *$ & $\begin{array}{l}0.1008 \\
(2.89)\end{array}$ & $* * *$ \\
\hline $\ln (\mathrm{w} / \mathrm{p})$ & $\begin{array}{c}0.1566 \\
(0.74)\end{array}$ & & $\begin{array}{l}0.1925 \\
(1.31)\end{array}$ & & $\begin{array}{l}0.5237 \\
(3.09)\end{array}$ & $* * *$ \\
\hline $\ln \left(\mathrm{p}_{\mathrm{M}} / \mathrm{p}\right)$ & $\begin{array}{l}0.9762 \\
(4.05)\end{array}$ & $* * *$ & $\begin{array}{l}-0.1884 \\
(-1.15)\end{array}$ & & $\begin{array}{l}-0.601 \\
(-3.07)\end{array}$ & $* * *$ \\
\hline lagged dependent variable & $\begin{array}{l}0.3964 \\
(7.43)\end{array}$ & $* * *$ & $\begin{array}{l}0.6181 \\
(4.22)\end{array}$ & $* * *$ & $\begin{array}{l}0.658 \\
(7.86)\end{array}$ & $* * *$ \\
\hline Constant term & $\begin{array}{l}7.1921 \\
(4.03)\end{array}$ & $* * *$ & $\begin{array}{l}1.4985 \\
(1.09)\end{array}$ & & $\begin{array}{c}0.9046 \\
(0.53)\end{array}$ & \\
\hline $\begin{array}{l}\text { Test statistics of } \\
\text { serial correlation }\end{array}$ & -1.2881 & & -1.1023 & & -1.1814 & \\
\hline Number of observations & 1907 & & 1907 & & 1907 & \\
\hline
\end{tabular}

Notes: The coefficient estimates of year dummies are suppressed. 
Table 10 Estimation Results of the Determinants of Arable Land Utilization as Rice Production

\begin{tabular}{|c|c|c|c|c|}
\hline \multirow[b]{2}{*}{ Land productivity } & \multirow{2}{*}{$\begin{array}{c}\begin{array}{c}\text { efficient rice } \\
\text { producer }\end{array} \\
0.0022 \\
(2.08)\end{array}$} & \multicolumn{3}{|c|}{$\begin{array}{l}\text { inefficient rice } \\
\text { producer }\end{array}$} \\
\hline & & $* *$ & $\begin{array}{l}0.0038 \\
(3.95)\end{array}$ & $* * *$ \\
\hline Number of parcels & $\begin{array}{r}0.0027 \\
(1.95)\end{array}$ & * & $\begin{array}{l}0.002 \\
(2.00)\end{array}$ & $* *$ \\
\hline Dummy for participation in cultivation accords & $\begin{array}{r}0.0084 \\
(0.37)\end{array}$ & & $\begin{array}{r}0.0239 \\
(1.09)\end{array}$ & \\
\hline Dummy for participation in joint utilization & $\begin{array}{r}-0.0267 \\
(-1.47)\end{array}$ & & $\begin{array}{l}-0.0508 \\
(-3.38)\end{array}$ & $* * *$ \\
\hline Dummy for participation in consignment contract & $\begin{array}{r}-0.0643 \\
(-2.02)\end{array}$ & $* *$ & $\begin{array}{l}-0.0542 \\
(-2.22)\end{array}$ & $* *$ \\
\hline Outstanding loan balance & $\begin{array}{r}0.0015 \\
(1.18)\end{array}$ & & $\begin{array}{r}0.0012 \\
(1.49)\end{array}$ & \\
\hline Crop prospects relative to normal years & $\begin{array}{l}-0.1074 \\
(-1.79)\end{array}$ & $*$ & $\begin{array}{l}-0.1557 \\
(-3.38)\end{array}$ & $* * *$ \\
\hline $\begin{array}{l}\text { Proportion of farm area not disposed of or in lots of } \\
\text { less than } 10 \mathrm{a}\end{array}$ & $\begin{array}{l}-0.1001 \\
(-3.38)\end{array}$ & $* * *$ & $\begin{array}{l}-0.0541 \\
(-1.77)\end{array}$ & $*$ \\
\hline $\begin{array}{l}\text { Proportion of farm area in lots more than or equal } \\
10 \text { a and less than } 20 \text { a }\end{array}$ & $\begin{array}{l}-0.0841 \\
(-3.07)\end{array}$ & $* * *$ & $\begin{array}{l}-0.003 \\
(-0.10)\end{array}$ & \\
\hline $\begin{array}{l}\text { Proportion of farm area in lots more than or equal } \\
20 \text { a and less than } 30 \text { a }\end{array}$ & $\begin{array}{l}-0.0797 \\
(-3.01)\end{array}$ & $* * *$ & $\begin{array}{c}-0.0038 \\
(-0.13)\end{array}$ & \\
\hline $\begin{array}{l}\text { Proportion of farm area in lots more than or equal } \\
30 \text { a and less than } 50 \mathrm{a}\end{array}$ & $\begin{array}{l}-0.0283 \\
(-0.98)\end{array}$ & & $\begin{array}{c}-0.0172 \\
(-0.59)\end{array}$ & \\
\hline Dummy for certified farmers & $\begin{array}{l}-0.0646 \\
(-5.48)\end{array}$ & $* * *$ & $\begin{array}{c}-0.0313 \\
(-2.98)\end{array}$ & $* * *$ \\
\hline Tohoku & $\begin{array}{r}0.0462 \\
(1.77)\end{array}$ & $*$ & $\begin{array}{r}0.0637 \\
(2.60)\end{array}$ & $* * *$ \\
\hline North Kanto \& Koshin & $\begin{array}{r}0.0096 \\
(0.32)\end{array}$ & & $\begin{array}{r}0.0907 \\
(3.25)\end{array}$ & $* * *$ \\
\hline South Kanto & $\begin{array}{c}0.1722 \\
(4.73)\end{array}$ & $* * *$ & $\begin{array}{r}0.1915 \\
(5.74)\end{array}$ & $* * *$ \\
\hline Hokuriku & $\begin{array}{r}0.1016 \\
(3.47)\end{array}$ & $* * *$ & $\begin{array}{r}0.1425 \\
(5.12)\end{array}$ & $* * *$ \\
\hline Tokai & $\begin{array}{r}0.0448 \\
(1.23)\end{array}$ & & $\begin{array}{r}0.0986 \\
(2.78)\end{array}$ & $* * *$ \\
\hline Kinki & $\begin{array}{l}0.017 \\
(0.50)\end{array}$ & & $\begin{array}{r}0.0242 \\
(0.71)\end{array}$ & \\
\hline Chugoku & $\begin{array}{l}-0.028 \\
(-0.84)\end{array}$ & & $\begin{array}{r}0.0535 \\
(1.62)\end{array}$ & \\
\hline Shikoku & $\begin{array}{l}0.052 \\
(1.44)\end{array}$ & & $\begin{array}{r}0.0952 \\
(2.47)\end{array}$ & $* *$ \\
\hline Kyusyu & $\begin{array}{l}-0.054 \\
(-1.77)\end{array}$ & * & $\begin{array}{r}0.0583 \\
(1.91)\end{array}$ & * \\
\hline Constant term & $\begin{array}{l}0.7943 \\
(15.56)\end{array}$ & $* * *$ & $\begin{array}{l}0.6549 \\
(17.24)\end{array}$ & $* * *$ \\
\hline Determinants of coefficient & 0.1698 & & 0.1361 & \\
\hline Number of observations & 1587 & & 1912 & \\
\hline
\end{tabular}

Notes: The coefficient estimates of year dummies are suppressed. 


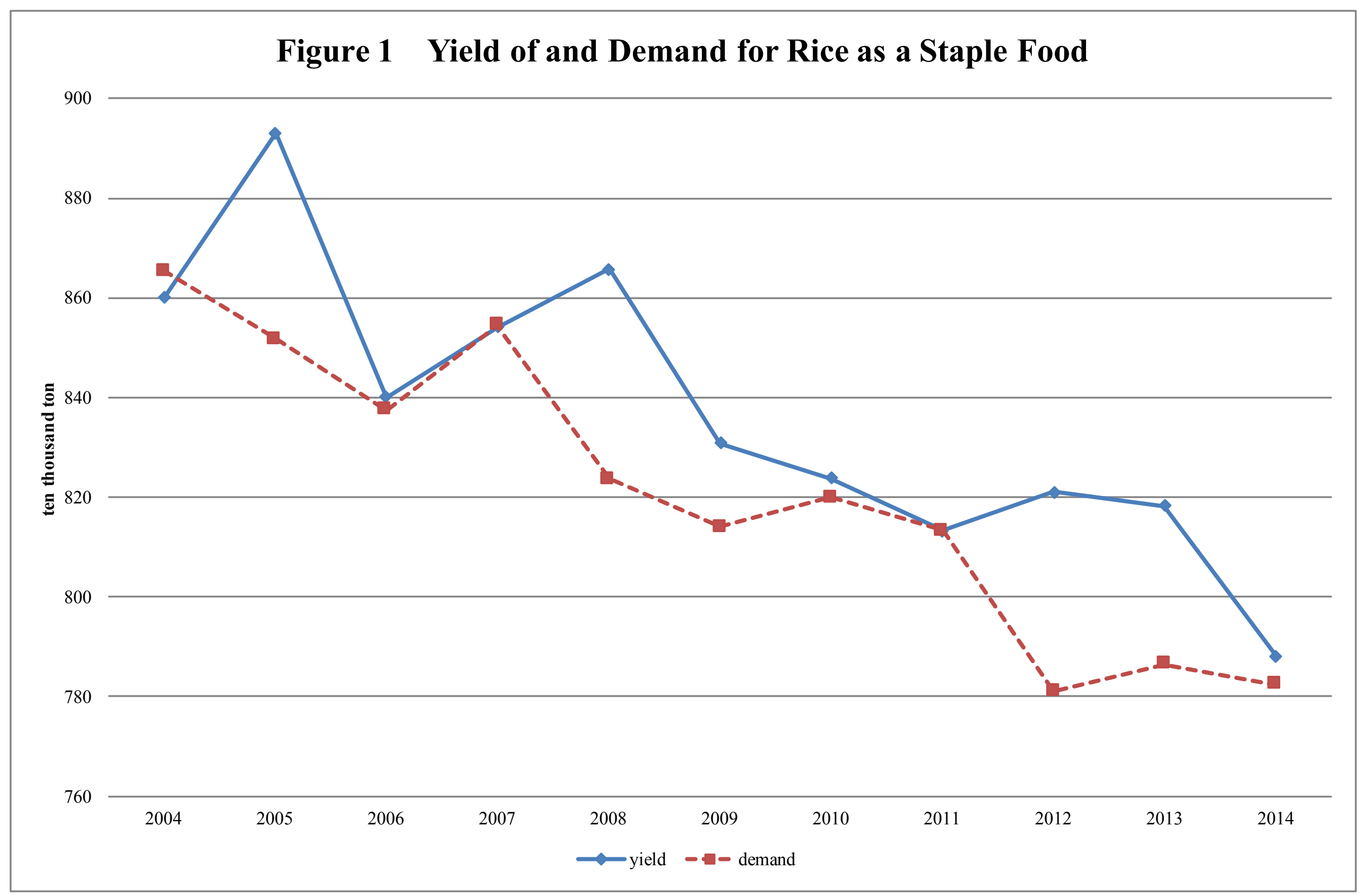

Source: Ministry of Agriculture, Forestry and Fisheries, Situations about Rice, Basic Principles on Demand and Supply of Rice and Price Stabilization 


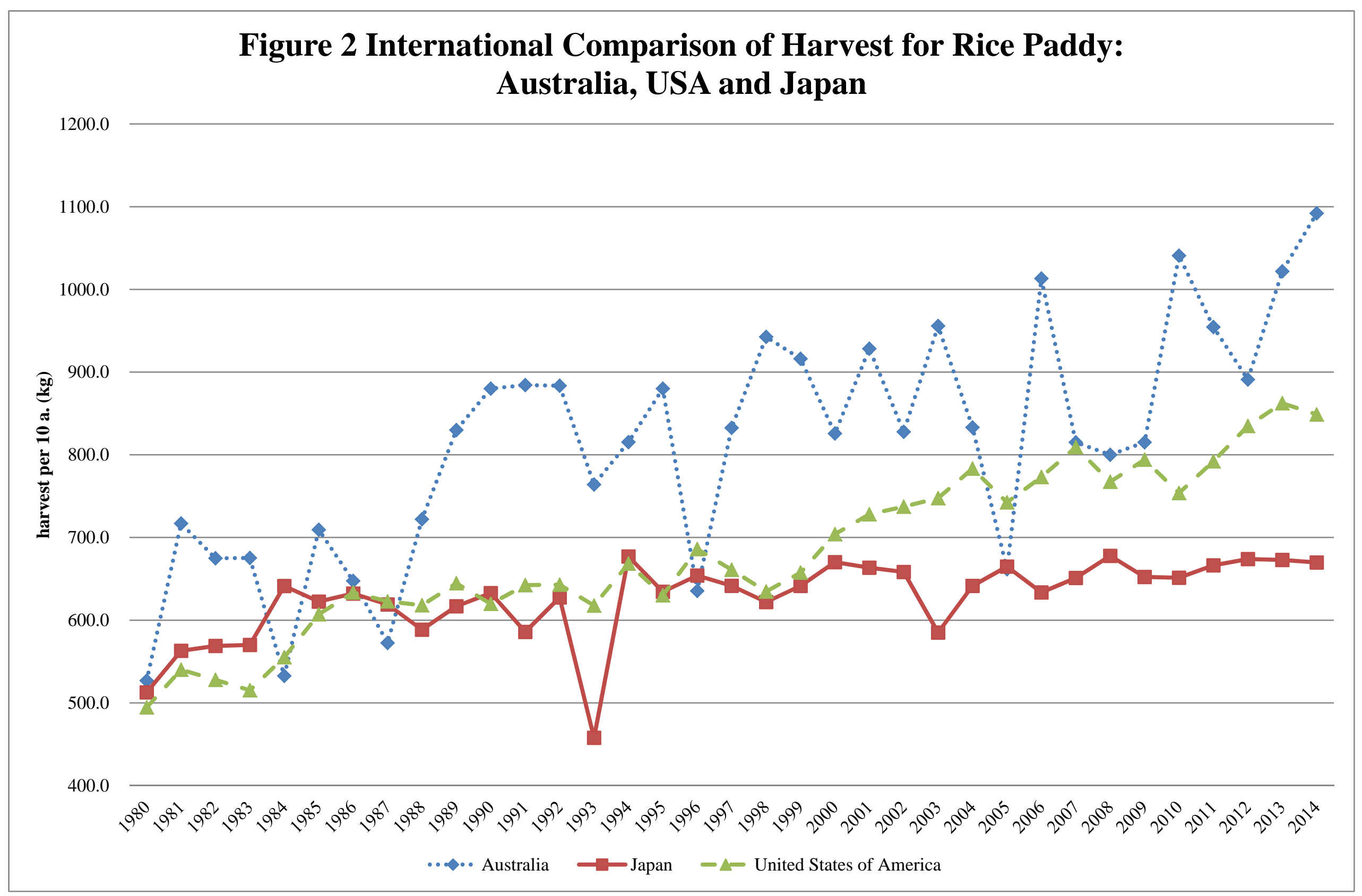

Source:Food and Agriculture of the United Nations, FAOSTAT 
Figure 3 Histogram of Land Productivity

(a) Efficient Rice Producer

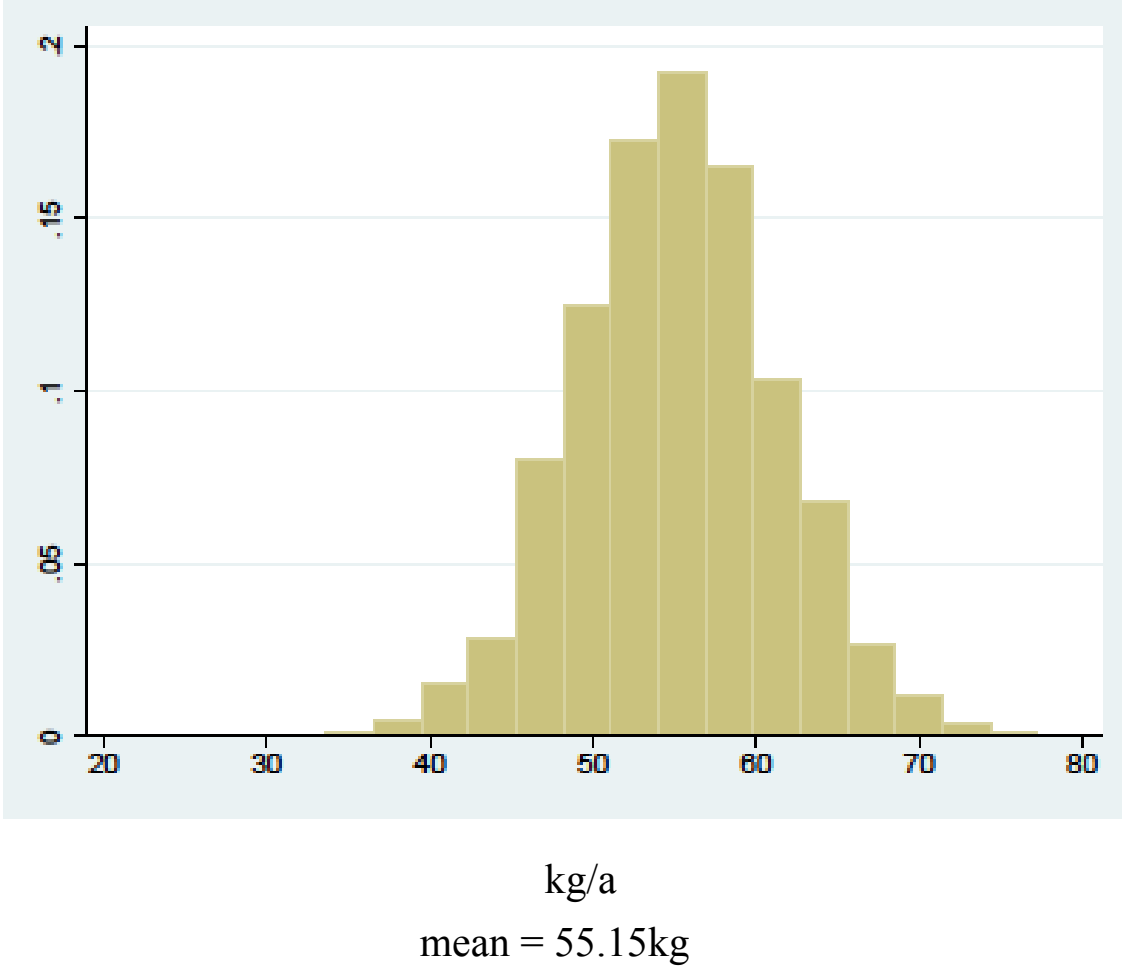

(b) Inefficient Rice Producers

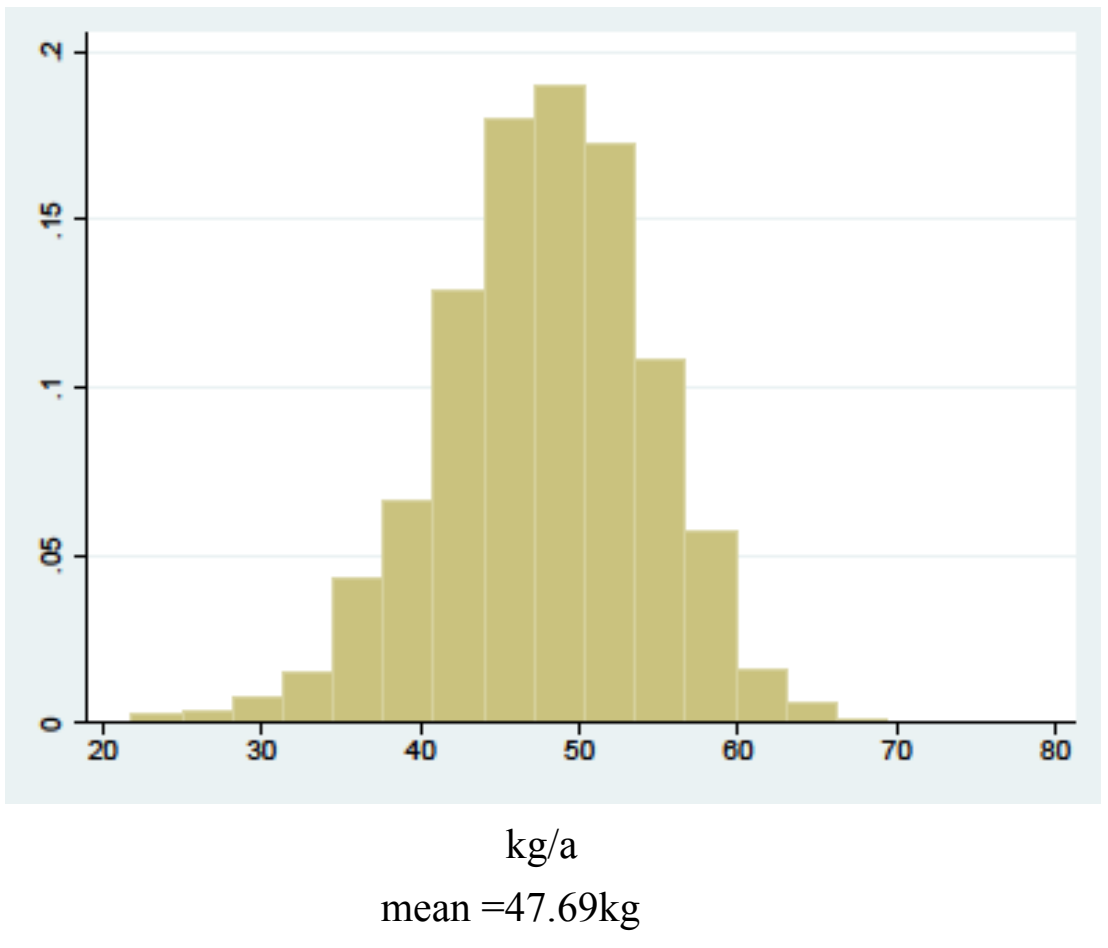

